\title{
Relationship between Motivation and College Students Learning Outcomes on Chemical Kinetic Material at University
}

\author{
Agus Muliaman \\ Program of Postgraduate, \\ State University of Medan \\ Medan, Indonesia \\ email : agusmuliaman@gmail.com
}

\author{
Retno Dwi Suyanti \\ Program of Postgraduate, \\ State University of Medan \\ Medan, Indonesia
}

\author{
Eddiyanto \\ Program of Postgraduate, \\ State University of Medan \\ Medan, Indonesia
}

\begin{abstract}
The level of quality of education within a country is a manifestation of the government towards the progress of its people. One indicator of the quality of education is the learning outcomes achieved by students. One of the factors that determine student learning outcomes is learning motivation. Motivated students tend to seek meaningful and meaningful academic activities for themselves, so that learning outcomes increase. This study aims to determine the relationship between learning motivation with student learning outcomes at Medan State University. This research applies experimental research through correlational design. The population in this study is all students of FMIPA semester 1 who follow the Basic Concept of Chemistry course in the academic year 2017/2018. The sampling technique is purposive sampling. The sample of this research is regular class students of chemical education $\mathbf{C}$ and Mathematics education $\mathrm{C}$. Instrument research in the form of objective test of learning result valid and reliable, motivation questionnaire. This study uses statistical analysis techniques using regression analysis. The findings of this study indicate that learning motivation significantly correlated with student learning outcomes, with $\mathbf{r}_{\mathrm{xy}}$ value $=0.712$ and obtained coefficient of determination $\left(r^{2}\right)$ of 0,507 . The results recommend that the university administer the assisted learning program that can help students to motivate themselves in improving learning outcomes.
\end{abstract}

Keywords-Motivation, Learning Outcomes, chemical kinetic

\section{INTRODUCTION}

Education is one form of human embodiment that is dynamic and full of development. Therefore, the development of education is the right thing done by society [1]. The quality of education in Indonesia is still low. The Learning Curve Pearson 2014, a world education rating agency, states that Indonesia ranks last in the quality of education in the world, while in 2015 the quality of education in Indonesia is still in
10 countries with low quality of education, School Ranking [2].

One of the indicators that affect the quality of education in Indonesia is the learning outcomes. Student learning outcomes Indonesia is still relatively low. Learning difficulties lie in the gap that occurs between understanding concepts and applying existing concepts that lead to difficult assumptions to learn and develop them [3]. Good learning outcomes require preparation of each learning component, one of which is learning motivation [4].

In the learning process, motivation is one of the predicted factors that influence the learning outcomes. students with high motivation are expected to obtain good learning outcomes. The importance of motivation is shaped to transform learning into a more positive direction. Achievements will be better if they have high motivation [5]. According to Arikunto, in the process of teaching and learning, lecturers should be able to help students to improve understanding so as to obtain better results [6]. Wena said explaining without the motivation of high student learning will be difficult for to achieve optimal learning outcomes [7].

Several studies have shown that student motivation is a significant dimension for learning outcomes. Pape, Bell and Yetkin state that motivated students can manage time to learn, so as to produce the best results [8]. Patimah said that there is a correlation between learning motivation and students using IPS class IV SDN 18/1 Teluk Village [9]. Research by Palupi, Anitah and Budiyono in particular on junior high school students showed positive with motivation to learn in Science of Junior High School N 1 Pacitan [10]. Other studies by Amrai and friends show that academic motivation has a significant effect on student achievement [11].

Based on the above description that one of the components that can be used to strengthen student learning outcomes is the 
motivation to learn. In this article will be described the results of research trying to explain the relationship between motivation with student learning outcomes on kinetika materials at the university. So the results of this study is expected to be a reference material for quality improvement in Indonesia, especially in related universities.

\section{RESEARCH METHOD}

This research is a experimental research with correlational design. Correlational design is to study the phenomenon of relationships between variables as existing or naturally [10]. Correlation statistics are used to measure the strength of a relationship or to predict effective contributions affecting variables, which is multivariate correlation statistics. Multivariate correlation statistics are used when using three or more variables [12]. Data analysis used in simple regression analysis.

This research was conducted at State University of Medan, Faculty of Mathematics and Natural Sciences, Chemistry Department, chemistry education academic semester 1 academic year 2017/2018 from September 2017 to February 2018. Population in this research is all of FMIPA student of semester 1 which follow Basic Chemistry Concept course in Academic Year 2017/2018 at Universitas Negeri Medan which amounts to about 840 students. The population is the target that becomes the object of research to be studied, the totality of all possible values, the results of counting or quantitative or qualitative measurement [13]. The sample in this study is the students in 2 regular classes in the first semester of academic year 2017/2018 that is Chemistry dik C and Mathematics dik $\mathrm{C}$ taken by purposive sampling which amounts to 60 students. The sample is defined as part of the population that is the source of actual data in the study [13].

Data analysis technique used in this research is statistical analysis by using regression analysis. Regression analysis used in this research is simple regression analysis. The usefulness of multiple regression analysis is to predict the value of the dependent variable (Y) if the independent variable (X).

\section{RESEARCH RESULTS AND DISCUSSION}

The results were analyzed by using simple regression analysis. Results of data analysis using SPSS obtained the following results:

TABLE 1. Model Summary

\begin{tabular}{|r|r|r|r|r|}
\hline Model & R & R Square & $\begin{array}{c}\text { Adjusted } \\
\text { R Square }\end{array}$ & $\begin{array}{c}\text { Std. } \\
\text { Error of } \\
\text { the } \\
\text { Estimate }\end{array}$ \\
\hline 1 & $.712^{\mathrm{a}}$ & .507 & .499 & .102127 \\
\hline
\end{tabular}

The results showed that there is a significant relationship between motivation and learning outcomes. The value of correlation or relationship $\left(\mathrm{r}_{\mathrm{xy}}\right)$ of 0.715 and obtained coefficient of determination $\left(\mathrm{r}^{2}\right)$ of 0,507 which means that the level of single learning motivation contributes to the learning results of $50,7 \%(0,507 \times 100 \%)$, while the rest of $49,3 \%$ predicted by other variables.

The existence of findings that consistently show correlations and influences that imply that learning outcomes are determined by motivational factors. The link between motivation and cognitive aspects (learning outcomes) is reinforced by Alhadi and Syahputra research which states that: the motivation to learn has a relationship with learning outcomes. The effect of learning motivation on learning outcomes is $21.5 \%$. Motivation is the passion and development of strategies that increase the likelihood of desired outcomes.

In addition, other studies conducted by Trinora, Riswandi \& Mustakim identified patterns of relationship between learning motivation and student learning outcomes. this study shows a tendency for higher learning motivation, better or higher student learning outcomes [17].

The same study was also conducted by Abuameerh \& Al Saudi who concluded that there is a significant difference in student achievement motivation due to academic achievement. Graduating students showed greater motivation than failed students [13].

Then another study was conducted by Emmanuel et al. which identifies students' achievement motivation and student achievement. The results show that most high school students, who have high motivation, have high self-concept and have good achievement on Mathematics achievement test [14].

Academic motivation that may affect academic achievement is influenced by the home environment. The research findings from Muola have supported previous findings that have shown a positive relationship between achievement motivation and home environment. The home environment is one of the determinants of academic achievement motivation [22].

The results of this study and some previous research results have shown that learning motivation is an important aspect for achievement of learning outcomes. Students who have great motivation to learn will show interest, concentration, persistence in process and learning outcomes. Conversely, students who lack the motivation to learn will show boredom, easy to despair, and try to avoid learning activities.

Motivation to learn has a significant effect on the quality of learning outcomes. Learning motivation encourages students to increase their enthusiasm and persistence in learning. In addition, learning motivation plays an important role in providing encouragement, encouragement, and pleasure in learning activities. This will encourage students to improve learning outcomes. If the motivation to study students is low, this certainly will not cause encouragement and a sense of enthusiasm to learn, so the results of learning tend to be low. 


\section{CONCLUSION}

Based on the results of data analysis research conducted it can be concluded that there is a relationship between motivation with students' chemical learning results with rxy value $=0.712$ and obtained coefficient of determination (r2) of 0,507. Sourced from this research, it is necessary to hold efforts made by lecturers and educational institutions such as universities to improve student motivation so that the learning outcomes also increase.

\section{REFERENCES}

[1] G. Sugiharti, and A. Muliaman, "Perbandingan Hasil Belajar Siswa yang Diajar Dengan Menggunakan Model Contextual Teaching And Learning dan Guided Inquiry pada Pokok Bahasan Struktur Atom," Jurnal Pendidikan Kimia, Vol. 8, pp. 5-11, April 2016.

[2] G. Raymond, Rendahnya kualitas pendidikan di Indonesia, 2017. [online 31 Oktober 2017], Accessed from: http://psychology.binus.ac.id.

[3] A. Muliaman, and L. M. Hutagaoul, "Improvement of Student Learning Outcome Using Model of Collaborative Based Lesson Study With Student,s Worksheet on Materials Hydrolys," Annual International Seminar on Transformative Education and Educational Leadership (AISTEEL), Vol. 2, pp. 141-145, Desember 2017.

[4] S. Alhadi, and W. N. E. Saputra, "The Relationship between Learning Motivation and Learning Outcome of Junior High School Students in Yogyakarta," Advances in Social Science Education and Humanities Research (ASSEHR), Vol. 66, pp. 138-141, 2017.

[5] E. Prayitno, Motivasi dalam Belajar, Jakarta: PPLPTK Depdikbud, 1989.

[6] S. Arikunto, Prosedur Penelitian, Jakarta: Rineka Cipta, 2013.
[7] M. Wena, Strategi Pembelajaran Inovatif Kontemporer, Jakarta: Bum Aksara, 2011.

[8] S. Pape, C. Bell, and I. Yetkin, "Developing mathematical thinking and self-regulated learning: A teaching experiment in a seventh grade mathematics classroom," Education Study Matheamtics, vol. 53, pp 179-202 ST-Developing mathematical thinking and, 2003.

[9] S. Patimah. Hubungan Motivasi Belajar dengan Hasil Belajar Siswa pada Mata Pelajaran Ilmu Pengetahuan Sosial Kelas IV SD Negeri 18/I Desa Teluk, 2014. [Online 6 October 2017], Accessed from: ecampus.fkip.unja.ac.id.

[10] R. Palupi, S. Anitah, and Budiyono, "Hubungan antara Motivasi Belajar dan Persepsi Siswa Terhadap Kinerja Guru Dalam Mengelola Kegiatan Belajar Dengan Hasil Belajar IPA Siswa Kelas Viii di SMPN N 1 Pacitan," Jurnal Teknologi Pendidikan dan Pembelajaran, vol. 2, no. 2 pp. 157-170, 2014.

[11] J. A. Glover \& R. H. Bruning. Educational Psychology: Principles and Application. Columbus: Charles E. Merril Publishing Company, 1990.

[12] M. D. Gall, J. P. Gall, R. W. Borg. Educational Research: an Introduction. New York: Longman, 2003.

[13] N. Sudjana, Penilaian Hasil Proses Belajar Mengajar, Bandung: PT Remaja Rosdakarya, 2009

[14] R. Trinora, R. Riswandi, \& E. Mustakim, "Hubungan Motivasi Belajar dan Hasil Belajar Siswa," Jurnal Pedagogi, vol 3, no. 1, 2015.

[15] O. A. Abuameerh and M. Al Saudi, "The Relationship between Achievement Motivation and Academic Achievement for Secondary School Students at Salt in Jordan," Dirasat: Educational Sciences, vol. 39, no. 1, pp. 313-320, 2012.

[16] A.-O. Emmanuel, E. A. Adom, B. Josephine, and F. K. Solomon, "Achievement Motivation, Academic Self-Concept and Academic Achievement Among High School Students," European Journal of Research and Reflection in Educational Sciences, vol. 2, no. 2, pp. 24 37, 2014.

[17] J. M. Muola, "A study of the relationship between academic achievement motivation and home environment among standard eight pupils," Educational Research and Reviews, vol. 5, no. 4, pp. 213-217, 2010 